\author{
Rafał Kamiński \\ Uniwersytet Warszawski \\ rafal.kaminski87@gmail.com
}

\title{
Wybrane aspekty polityki zagranicznej Australii u progu XXI wieku
}

\begin{abstract}
Streszczenie: Polityka zagraniczna Australii, tradycyjnie zorientowana głównie na relacje z USA, uległa w ostatnich latach wielu zmianom. Ewolucja układu sił w globalnej polityce, odczuwalna najbardziej w regionie Azji Wschodniej, doprowadziła do dowartościowania w oczach australijskich elit partnerów z najbliższego sąsiedztwa. Chiny, najważniejszy obecnie partner gospodarczy Canberry, ale również tradycyjnie największe zagrożenie dla regionalnej równowagi sił, aspirują do odgrywania kluczowej roli na obszarze Południowego Pacyfiku. Poprzez nawiązywanie porozumień o wolnym handlu z krajami należącymi do ASEAN-u i osobno z całą tą organizacją Australia próbuje zrównoważyć uprzywilejowaną pozycję Pekinu jako głównego partnera handlowego. Kolejnym krokiem w tym kierunku ma być zniesienie ceł w handlu z Koreą Południową i Japonią. Mój artykuł analizuje azjatycki zwrot $\mathrm{w}$ australijskiej polityce zagranicznej $\mathrm{w}$ ostatnich latach oraz przybliża treść dokumentów rządowych określających strategię działania, zarówno w kwestiach gospodarczych jak i militarnych, w nowych warunkach geopolitycznych.
\end{abstract}

Związek Australijski to jedno z najmłodszych państw należących do zachodniego kręgu cywilizacyjnego, którego niepodległość rodziła się w burzliwym okresie II Wojny Światowej na Pacyfiku i bardzo długo nosiła ślady powstałych wtedy obaw. Groźba japońskiej agresji, jaka zawisła wtedy nad Australią na bardzo długo ukształtowała sposób postrzegania Azji w polityce zagranicznej tego państwa. Rozpad Imperium Brytyjskiego i powstanie nowych struktur politycznych $\mathrm{w}$ tym regionie dodatkowo pogłębiło ten proces. Wycofanie się Wielkiej Brytanii, metropolii i najbliższego sojusznika, z tego regionu jeszcze bardziej wzmocniło poczucie osamotnienia w niestabilnym środowisku. Naturalnym procesem była więc współpraca z nowym mocarstwem - Stanami Zjednoczonymi, które okazało się nie tylko 
zwycięzcą wojny, ale także nowym kluczowym rozgrywającym na obszarze Azji i Pacyfiku (Firth 2011: 14).

Zawarty w 1951 roku sojusz między Stanami Zjednoczonymi, Australią i Nową Zelandią gwarantował co prawda wsparcie militarne i utrwalał powstałą w trakcie wojny z Japonią strategiczną więź, ale z punktu widzenia relacji z państwami azjatyckimi był raczej przeszkodą $\mathrm{w}$ budowie wzajemnego zaufania i budowie trwałych relacji. Marsz komunizmu, najpierw zakończony sukcesem w Chinach, a później na Półwyspie Koreańskim i w Azji Południowo-Wschodniej, wywoływał nowe konflikty, w których sprzymierzona z USA Australia brała czynny udział. Dwublokowy podział świata i związane z nim zagrożenie ze strony ZSRR również składało się na brak zaufania do najbliższych sąsiadów, którzy w różnych okresach czasu znajdowali się, w mniejszym lub większym zakresie, w orbicie wpływów Moskwy.

Wszystkie te czynniki sprawiły, że przez blisko 50 lat swojej historii Australia była „odwrócona plecami” do Azji, a jej polityczna aktywność w tym rejonie świata była ściśle związana z aktywnością Stanów Zjednoczonych i udziałem w strategii powstrzymywania komunizmu. Niski poziom rozwoju gospodarczego nie skłaniał do budowania relacji handlowych, a rosnąca populacja państwa Azji Południowo-Wschodniej wzmagała, w społeczeństwie tradycyjnie niechętnym przybyszom spoza zachodniego kręgu kulturowego, obawy o napływ niekontrolowanej liczby nielegalnych imigrantów (Burke, 2007: 46).

Jedynym wyjątkiem od tej polityki dystansowania się były relacje z Japonią, które pomimo wojennych obciążeń rozwijały się bardzo dobrze już od momentu przejścia niedawnego agresora pod amerykańską okupację. Brak zagrożenia militarnego, związanego $\mathrm{z}$ rezygnacją Tokio z posiadania sił zbrojnych, przy jednoczesnej szybkiej odbudowie i wzroście gospodarczym tego kraju, przyczynił się do zbudowania przyjaznych relacji. Kluczowa rola Japonii w amerykańskiej strategii w Azji oraz rosnące zapotrzebowanie na surowce energetyczne, których Australia była i jest kluczowym eksporterem, sprzyjały budowaniu strategicznego partnerstwa (Terada, Ligang 2007: 54). Stabilny system polityczny, wspólne interesy handlowe oraz zaangażowanie $\mathrm{w}$ walkę $\mathrm{z}$ komunizmem $\mathrm{w}$ Azji - te trzy czynniki były kluczowe dla przezwyciężenia naturalnych obaw Canberry w traktowaniu Japonii jako partnera. Tak długo jak pozostałe państwa regionu nie spełniały tych warunków nie mogło być mowy o ściślejszej współpracy.

Zmiany jakie nastąpiły w Azji Wschodniej w ostatnich dwóch dekadach XX wieku nie pozostały bez wpływu na politykę zagraniczną Australii. Niezwykle dynamiczny rozwój najpierw „azjatyckich tygrysów”, a później Chińskiej Republiki Ludowej i państw ASEAN-u, stworzyło pierwszą płaszczyznę do porozumienia, które stopniowo przeobrażało obraz Azji w oczach 
Australijczyków. Upadek dyktatur wojskowych w Korei, na Tajwanie czy w Tajlandii i postępujący proces stabilizacji sytuacji politycznej w ChRL dawał nadzieję na przyjęcie przez te państwa wzorców demokracji liberalnej (Mediansky 1997: 191). Dla elit politycznych było jasne, że gospodarczo, dzięki popytowi na żywność i surowce, Australia będzie w coraz większym stopniu stawać się częścią systemu gospodarczego Azji Wschodniej, a to $\mathrm{z}$ kolei wpłynie na poziom bezpieczeństwa $\mathrm{w}$ regionie.

\section{Australia wobec instytucjonalizacji stosunków międzynarodowych w Azji}

Australia próbując zdobyć polityczny przyczółek w Azji zaangażowała się $w$ budowę regionalnych struktur integracyjnych i organizacji międzynarodowych chcąc wykorzystać zbliżenie gospodarcze do normalizacji relacji politycznych. Oczywiście struktury te powstawały początkowo z inicjatywy Stanów Zjednoczonych, których celem była liberalizacja handlu w obszarze Pacyfiku, ale w połowie lat 90 . XX wieku proces ten zdominowały już same państwa azjatyckie, które doceniły korzyści płynące $\mathrm{z}$ instytucjonalizacji stosunków międzynarodowych. (Burke, 2007: 175)

Pierwszą ważną strukturą, w której utworzeniu Australia odegrała dużą rolę była powołana w 1989 roku w Canberrze Wspólnota Gospodarcza Azji i Pacyfiku (APEC, Asia-Pacific Economic Co-operation) zrzeszająca państwa leżące po obu stronach Oceanu Spokojnego. Głównym celem utworzenia tej organizacji jest liberalizacja handlu w obrębie Pacyfiku, a jej głównym inicjatorem były Stany Zjednoczone, dlatego obecność i aktywność Australii w nim od samego początku było dowodem na ścisłe powiązanie interesów gospodarczych tych, zarówno z rynkiem amerykańskim, jak i azjatyckim (Ravenhill, 2001: 115).

Ważnym krokiem dla kształtowania przyjaznych sąsiedzkich relacji było rozpoczęcie przez Australię bliskiej współpracy ze Stowarzyszeniem Narodów Azji Południowo-Wschodniej w formule Forum Regionalnego ASEAN (ARF). Inicjatywa ta powstała w 1994 roku, jako pole do dialogu i współpracy integrujących się państw Azji Południowo-Wschodniej z partnerami zarówno z najbliższego sąsiedztwa, jak również Unią Europejską, USA czy Rosją. Mając na uwadze konieczność stworzenia instytucjonalnych podstaw do rozmów o przeciwdziałaniu zagrożeniom mającym swoje źródło w Azji Wschodniej, Australia była jednym z członków-założycieli ARF (Williams, Newman 2006: 224). Azja Wschodnia przez cały okres zimnej wojny była polem licznym konfliktów, a po jej zakończeniu przez brak silnych struktur międzynarodowych stała się ona centrum transgranicznej, zorganizowanej przestępczości. 
Aby jeszcze ściślej uczestniczyć w koordynowaniu polityki we własnym sąsiedztwie Australia była jednym z inicjatorów stworzenia formuły cyklicznych spotkań szefów rządów i głów państw. W 2005 roku odbył się pierwszy Szczyt Azji Wschodniej (East Asia Summit), który miał pełnić taką rolę i sprzyjać budowie personalnych relacji między przywódcami największych państw regionu oraz Stanów Zjednoczonych i Rosji. Agenda spotkań jest niezwykle szeroka i obejmuje zarówno kwestie polityczne, ekonomiczne i społeczne, które przeplatają się ze sobą tworząc mozaikę problemów całego regionu.

Oczywiście działania w ramach inicjatyw multilateralnych nie ograniczają działań dwustronnych w budowaniu wizerunku Australii jako państwa wiarygodnego, otwartego i skłonnego do przezwyciężania nagromadzony stereotypów. Zawłaszcza ostatnie dwie kadencje rządów Partii Pracy pod przewodnictwem Kevina Rudda i Julii Gillard były okresem intensywnych działań w tym kierunku. Wielokrotne wizyty w Malezji, Indonezji, Wietnamie, a w ciągu ostatnich dwóch lat w Birmie, świadczą o dużej wadze, jaką australijskie elity przywiązują do relacji z tymi państwami.

Proces ten nie mógł pozostać bez wpływu na relację z dotychczasowymi partnerami ze Stanów Zjednoczonych i Europy, których pozycja w handlu zagranicznym zaczęła spadać. 0 ile pod względem inwestycji zagranicznych napływających do australijskiej gospodarki, dawna metropolia wciąż jest liderem i głównym inwestorem, o tyle statystyki australijskiego eksportu znacznie odchyliły się na korzyść Japonii, a zwłaszcza Chin, które od 2010 roku są głównym odbiorcą australijskich surowców.

\section{Australia i FTA}

Zmiany te odzwierciedla zapoczątkowany w 1983 roku proces zawierania dwustronnych umów o wolnym handlu, które stały się motorem napędowym wymiany towarów między Australią a najszybciej rosnącymi gospodarkami regionu. Pierwszą taką umowę zawarto z najbliższym partnerem, zarówno pod względem geograficznym, jak i kulturowo-cywilizacyjnym, Nową Zelandią. The Australia New Zealand Closer Economic Relations Trade Agreement zniosła jakiekolwiek taryfy celne w obrocie między tymi państwami i doprowadziła do harmonizacji przepisów o podejmowaniu działalności gospodarczej (Australia's Trade Agreements 2012). Jednocześnie ustanowiła wspólne standardy z zakresu kontroli jakości, w szczególności w odniesieniu do produktów rolnych, oraz zapewniła wzajemne uznawanie kwalifikacji i dyplomów. Umowa ta czyni z tych największych gospodarek Południowego Pacyfiku jeden silny zintegrowany organizm, w którym roczne obroty handlowe wyniosły blisko 22 miliardów dolarów. 
Pozytywne skutki tej współpracy oraz coraz większy udział partnerów azjatyckich w australijskim bilansie handlowym skłoniły rząd do rozpoczęcia tego typu negocjacji na szerszą skalę. Naturalnym kierunkiem rozwoju tego rodzaju współpracy i zacieśniania więzi gospodarczych była Azja Południowo-Wschodnia, w której proces liberalizacji handlu już trwał dzięki podpisanej w 1992 roku przez Brunei, Indonezję, Malezję, Filipiny, Singapur i Tajlandię umowie międzynarodowej powołującej do życia ASEAN Free Trade Area (AFTA) (ASEAN Free Trade Area 2012).

W 2003 roku drugą w historii umowę o wolnym handlu Australia zawarła z najlepiej rozwiniętym gospodarczo państwem regionu, Singapurem (Australia's Trade Agreements 2012). Położono w niej główny nacisk na natychmiastową redukcję wszystkich ceł, a także na kwestie swobody przepływu usług bankowych i finansowych. Osobnym osiągnięciem tego porozumienia było ułatwienie procedur wizowych dla osób, które podróżowały między oboma państwami w celach biznesowych w okresach nie dłuższych niż trzy miesiące.

Niezwykle ważny w tym procesie okazał się rok 2005, w którym w życie weszły kolejne dwie umowy o wolnym handlu, z Tajlandią i USA, oraz rozpoczęto kluczowe z tego punktu widzenia negocjacje z Chińską Republiką Ludową. W przypadku Tajlandii, porozumienie zakłada ograniczenie stawek celnych na większość towarów, choć nie na wszystkie, w tym w szczególności porozumienie pomija żywność, rozkładając proces redukcji barier celnych w niektórych kategoriach nawet do 2025. Jego istotną rolą jest umożliwienie australijskim firmom funkcjonowania na rynku usług oraz zapewnienie szerokiego pakietu gwarancji, ochrony i preferencji dla australijskich inwestycji zagranicznych w Tajlandii (Australia's Trade Agreements 2012).

Umowa ze Stanami Zjednoczonym jest znacznie bardziej złożona i w pełni odzwierciedla złożone relacje gospodarcze pomiędzy partnerami po obu stronach Pacyfiku. Przede wszystkim można zauważyć dużą niechęć USA do otwierania swojego rynku na produkty rolne z Australii, które zostały objęte częściową redukcją ceł tylko w około 75 procentach. W pozostałych sektorach ograniczenia taryfowe, również zakładają stopniowe znoszenie barier rozłożone do 2015. Najbardziej zliberalizowanym segmentem współpracy są natomiast inwestycje zagraniczne, których swobodny przepływ i promocja zostały uznane za jeden z najważniejszych elementów tej umowy (Australia's Trade Agreements 2012). Pokazuje to jak ograniczone pole manewru mają Australijczycy w budowaniu trwałego partnerstwa z USA w oparciu o aspekty gospodarcze i handel, który w kluczowych kategoriach, takich jak żywność, napotyka na bariery podatkowe mimo podpisanej umowy o wolnym handlu. 
Znacznie lepiej wygląda współpraca z Chile, które było kolejnym państwem, z którym Australia podpisała taką umowę. Oprócz stopniowego zniesienia ceł na wszystkie produkty do 2015 roku, udało się otworzyć chilijski rynek na australijskie usługi i inwestycje, szczególnie istotne w przypadku przemysłu wydobywczego, który odpowiada za największą część bogactwa narodowego. Ostatnim państwem z jakim sfinalizowano negocjacje w sprawie liberalizacji obrotów handlowych jest od stycznia 2013 roku Malezja (Australia's Trade Agreements 2012).

Jednak oprócz bilateralnych umów o wolnym handlu Australia jest także stroną wielostronnego porozumienia w tym zakresie. W 2010 roku weszła w życie umowa dająca możliwość zbudowania strefy walnego handlu w obrębie dwóch podmiotów gospodarczych: rynku australijsko-nowozelandziego oraz ASEAN-u (Australia's Trade Agreements 2012) ASEAN-Australia-New Zealand FTA nie objęła od samego początku wszystkich państw Azji Południowo-Wschodniej skupionych w tej organizacji, ale miała się stopniowo rozszerzać. Ma to związek $\mathrm{z}$ procesem integracji gospodarek w ramach samego ASEAN-u, który jest niezwykle złożony z racji wysokich różnic w poziomie rozwoju gospodarczego. Państwom, takim jak Birma czy Wietnam, pozostawiono więcej czasu na implementację postanowień tej umowy. Od stycznia 2012 AANZFTA obejmuje już wszystkie 12 państw sygnatariuszy, którzy zobowiązali się do zniesienia barier w przepływie towarów, usług, inwestycji oraz do ochrony własności intelektualnej. Jest to najbardziej kompleksowa umowa gospodarcza jaką zawarł ASEAN, tworząca realne możliwości działania dla australijskich przedsiębiorców i inwestorów.

Proces liberalizacji wymiany handlowej Australii z państwami azjatyckimi trwa oczywiście dalej, choć napotyka na wiele przeszkód ze strony największych gospodarek $\mathrm{w}$ regionie. Oczywiście najistotniejszą rolę ze względu na wartość wymiany mają umowy o wolnym handlu z Chinami i Japonią, negocjowane odpowiednio od 2005 i 2007 roku. Sytuacja obu tych gospodarek jest diametralnie różna, co zdecydowanie wpływa na tempo rozmów.

W przeciwieństwie do Chin, przeżywających okres stabilnego wzrostu, dla których umowa ta ma niewielkie znaczenie, dla Japonii, poszukującej od wielu lat bodźców do przezwyciężenia trwającego od końca lat 90 . XX wieku kryzysu, jest ona istotnym krokiem do odbudowy pozycji głównego partnera handlowego Australii. Na przeszkodzie staje jednak kwestia redukcji ceł na produkty rolne, które mają chronić japońskich producentów. Australia jest jednym z głównych eksporterów produktów rolnych, których importu boją się japońscy farmerzy (KYODO 2012).

Wzrost doświadczenia w negocjowaniu FTA i wymierne efekty znoszenia barier w handlu międzynarodowym w regionie Azji Wschodniej dopro- 
wadziły do rozpoczęcia rozmów o zniesieniu ceł z kolejnymi państwami; w 2010 roku z Indonezją, a w 2011 roku z Indiami, których mocarstwowe ambicje, także w sferze gospodarczej, wykraczają już daleko poza obszar Azji Południowej.

Australia nie chcąc rezygnować z obecności w APEC, aktywnie włączyła się również $\mathrm{w}$ amerykańską inicjatywę utworzenia strefy wolnego handlu w regionie Azji i Pacyfiku. W rozpoczęte w 2010 roku negocjacje zmierzające do utworzenia Partnerstwa Transpacyficznego (TPP) zaangażowanych jest obecnie 11 państw z Ameryki Północnej, Południowej oraz regionu Azji i Pacyfiku (Paul 2012: 31). Australia poprzez udział w tym projekcie, mającym ambicje otworzenia drogi do ścisłej integracji ekonomicznej w basenie Pacyfiku, łączy swoje ścisłe powiązania gospodarcze z USA $\mathrm{z}$ doświadczeniem $\mathrm{w}$ negocjacjach $\mathrm{z}$ azjatyckimi partnerami i może być pomostem $\mathrm{w}$ budowie porozumienia między zaangażowanymi $\mathrm{w}$ ten projekt gospodarkami regionu. Taka postawa jest dowodem odpowiedzialności elit politycznych w Canberrze, które starają się wciąż zdywersyfikować kierunki współpracy gospodarczej i mimo najlepszej $\mathrm{w}$ dziejach tego państwa koniunktury gospodarczej nie przestają szukać kolejnych partnerów i angażować się w projekty integracyjne. 0 ile pod względem politycznym Australia wciąż pozostaje związana bliskim sojuszem tożsamości i wartości ze światem euro-atlantyckim, o tyle w kwestiach ekonomicznych jest integralną częścią sytemu państwo-gospodarczego Azji Wschodniej.

\section{Australia in the Asian Century White Paper}

Australijskie kręgi rządowe mając świadomość historycznych zmian w międzynarodowym układzie sił, którego transformacja w ostatnich dwóch dekadach dowartościowała Azję jako najważniejszy obecnie region w stosunkach międzynarodowych, postanowiły wykorzystać tę dziejową szansę. Australia, od zawsze położona na peryferiach globalnej polityki i ekonomii, znalazła się nagle w bliskim sąsiedztwie najszybciej rozwijającego się regionu świata, który potrzebuje ogromnych ilości surowców. Te niezaspokajane potrzeby doprowadziły do historycznego wzrostu zysków z eksportu australijskiego węgla i innych surowców, którego wartość osiągnęła w 2012 roku blisko 150 miliardów dolarów australijskich (Australia 2013).

Próbując znaleźć sposób na utrwalenie tego trendu, nie tylko w wymiarze ekonomicznym, ale w znacznie szerszym ujęciu uwzględniającym wszystkie korzyści, jakie może przynieść bliska współpraca z azjatyckimi sąsiadami, stworzono dokument, który zawiera strategię działania w celu utrwalenia wszystkich pozytywnych skutków tej bliskiej współpracy do 
2025 roku. Australia in the Asian Century White Paper stanowi bez wątpienia wyraźny sygnał, iż polityka ignorowania państw azjatyckich jako równorzędnych partnerów została definitywnie zarzucona (Australia in the Asian Century White Paper 2012).

W tym liczącym ponad trzysta stron dokumencie opublikowanym w październiku 2012 znajdziemy szereg sugestii dla instytucji rządowych, władz stanowych, biznesu, instytucji kulturalnych oraz związków zawodowych, jak wykorzystać szansę na stabilny rozwój. Biała Księga wymienia pięć głównych obszarów, na których należy się skupić, aby utrwalić australijskie sukcesy w azjatyckim stuleciu jakim jest XXI wiek.

Pierwszym z nich jest przeprowadzenie skutecznych reform gospodarczych, które zwiększą konkurencyjność krajowych przedsiębiorstw, zwiększą poziom kapitału społecznego oraz przyciągną zagraniczne inwestycje. Wśród zapowiedzianych zmian wymienione są reformy sytemu podatkowego, unowocześnienie infrastruktury i deregulacja gospodarki. Skutkiem tych zmian ma być zwiększenie udziału innych sektorów gospodarki w budowie PKB i stopniowe zdywersyfikowanie przychodów z eksportu, których filarem są obecnie przemysł wydobywczy i rolnictwo.

Drugim obszarem jest szeroko rozumiana edukacja, której celem ma być podnoszenie kwalifikacji i zapewnienie stałego dopływu wysoko kwalifikowanych pracowników do australijskiej gospodarki. W szczególności wymienia się umiejętności techniczne, zdolność do adaptacji i odporność na zmieniające się trendy, a także kreatywność i myślenie nastawione na rozwiązywanie konkretnych problemów. Osobną kwestią jest konieczność wprowadzenia do szkół języków obcych w celu zbudowania społeczeństwa otwartego na kulturę państw azjatyckich i stworzenie możliwości do swobodnej komunikacji między Australijczykami a ich sąsiadami w Azji.

Kolejnym obszarem, w którym konieczne są zmiany jest struktura organizacyjna i zdolności do regionalnej współpracy w australijskich przedsiębiorstwach. W raporcie zwraca się uwagę, iż wzrost poziomu innowacyjności gospodarki jest możliwy dzięki współpracy z partnerami regionalnymi, których poziom rozwoju technologicznego stanowi wzór do naśladowania. Konieczna jest budowa nowych więzi i powiązań biznesowych gwarantujących nie tylko swobodny przepływ towarów i usług, ale także inwestycji, technologii i wiedzy.

Po czwarte wskazuje się na znaczenie bezpieczeństwa regionalnego w kontekście militarnym. Australia jako stabilne, demokratyczne państwo mające silną pozycję $\mathrm{w}$ organizacjach międzynarodowych, powinna angażować się we wszystkie regionalne inicjatywy, których celem jest zbudowanie bezpiecznego otoczenia międzynarodowego, a w ramach relacji dwustronnych powinna wzmacniać wizerunek wiarygodnego partnera. Szczególną rolę Biała Księga przypisuje sojuszowi ze Stanami Zjednoczonymi 
i ich obecności wojskowej w regionie, która pozytywnie wpływa na jego stabilność, choć zauważa równocześnie, że rola ta ulegnie zmianie, gdy Chiny zaczną aktywnie włączać się w regionalny system bezpieczeństwa jako jego wiarygodny uczestnik, zainteresowany przeciwdziałaniem konfliktom.

Po piąte wskazuje się na ogromną rolę instytucji pozarządowych w budowanie pozytywnego wizerunku Australii wśród azjatyckich partnerów i tworzenie silnych międzyludzkich więzi, które pozwolą przezwyciężyć różnice polityczne i ekonomiczne, tam gdzie nie można zrobić tego kanałami rządowymi. Australijczycy muszą lepiej poznać Azję, aby lepiej korzystać z owoców jej wzrostu, a Azjaci muszą lepiej poznać Australię, żeby dostrzec wszystkie możliwości, jakie otwiera przed nimi to państwo.

$\mathrm{Na}$ kolejnych stronach prezentowane są przyczyny tak gwałtownego sukcesu tego kontynentu w ostatnich latach oraz propozycje konkretnych działań we wspomnianych obszarach, które mają na celu zbliżenie tych dwóch światów, w celu osiągnięcia jak największych korzyści dla obu stron. Jest to opracowanie niezwykle pragmatyczne, pokazujące jak należy definiować interes narodowy w zmieniających się okolicznościach. Dla Australii „azjatyckie stulecie” stanowi niebywałą szansę na utrwalenie sukcesu gospodarczego zbudowanego na eksporcie węgla i pszenicy i stworzenie realnego partnerstwa z państwami azjatyckimi, także w obszarze kulturowym.

\section{Narodowa Strategia Bezpieczeństwa z 2013 roku}

Zgodnie $\mathrm{z}$ anglosaską tradycją najważniejsze zagadnienia $\mathrm{z}$ zakresu bezpieczeństwa i obronności były prezentowane w Australii wyłącznie w tzw. białych księgach, specjalnych dokumentach rządowych prezentujących sprawozdanie z realizacji postawionych wcześniej zadań, oceniających możliwości działania i kreślących cele na najbliższy okres (Defence White Paper 2009). Do roku 2013 wydano 5 Białych Ksiąg Obronności (w latach 1976, 1987, 1994, 2000 i 2009) jednak po raz pierwszy w 2013 roku przed opublikowaniem The Defence White Paper 2013, rząd wydał inny dokument kreślący główne interesy, zagrożenia i filary bezpieczeństwa narodowego zatytułowany: Strong and Secure: A Strategy for Australia's National Security. Celem tej publikacji jest ukazanie szerszego kontekstu pojęcia bezpieczeństwa narodowego, nie tylko $\mathrm{w}$ odniesieniu do kwestii obronności, ale również zagadnień gospodarczych i problemów społecznych (Strong and Secure 2013).

Jako najważniejsze filary bezpieczeństwa narodowego Strong and Secure wymienia osiem obszarów i zagadnień. Wśród nich znajdują się: zwalczanie terroryzmu i szpiegostwa, przeciwdziałanie i skuteczne reagowanie na akty agresji wobec Australii i jej interesów w regionie, ochrona szczelności 
granic, przeciwdziałanie, ściganie i zwalczanie międzynarodowej przestępczości, promowanie bezpieczeństwa i stabilności w środowisku międzynarodowych w celu stworzenia warunków do realizacji australijskich interesów, wzmacnianie odporności i zdolności reagowania na zagrożenia wobec obywateli, aktywów, infrastruktury i instytucji, sojusz ze Stanami Zjednoczonymi, rozumienie zmian jakie zachodzą we współczesnym świecie przy zachowaniu wpływ na ich kształt, ze szczególnym uwzględnieniem regionu Azji i Pacyfiku.

Spośród wszystkich wymienionych obszarów jeden wydaje się szczególnie ważny w kontekście strategicznych wyborów przed jakimi w najbliższych latach będzie stała Australia. Tym obszarem jest sojusz ze Stanami Zjednoczonymi. Jest to jedyna relacja dwustronna wymieniona wśród głównych punktów tego dokumentu, co bez wątpienia ma odzwierciedlać jej wyjątkową rolę. Autorzy wprost określają ją, jako najważniejszy australijski sojusz obronny, na którym opiera się polityka bezpieczeństwa państwa od zakończenia II Wojny Światowej, i jako niezwykle ważny czynnik w rozwoju własnych zdolności obronnych. USA są określane jako „kotwica” stabilności i bezpieczeństwa w regionie Azji i Pacyfiku.

Jednak partnerstwo to rozumiane jest szerzej niż tylko $\mathrm{w}$ odniesieniu do aspektów militarnych. To również gwarancja współpracy z państwem o podobnych korzeniach kulturowych i wspólnym dziedzictwie politycznym, które jest motorem napędowym dla światowej ekonomii. Oczywiście obecny kształt australijsko-amerykańskich relacji jest efektem wielu lat doświadczeń, niekiedy trudnych, jednak na tyle opłacalnych dla obu stron, iż mają zastosowanie w wielu wspólnych operacjach militarnych od Korei po Afganistan.

Wśród najważniejszych przejawów tej współpracy Narodowa Strategia Bezpieczeństwa wymienia regularne konsultacje na poziomie dyplomatycznym o raz wojskowym, wspólne ćwiczenia wojskowe, ze szczególnym uwzględnieniem kooperacji sił morskich, współpracę wywiadowczą, bardzo ważną $\mathrm{w}$ kontekście terroryzmu, który posiada swoje ogniska również w Azji Południowo-Wschodniej, a także współpracę w zakresie badań i rozwoju innowacyjnych projektów z zakresu obronności. Dostrzegając konieczność nie tylko utrzymania dotychczasowego poziomu relacji, ale także ich intensyfikacji autorzy strategii postulują kontynuowanie współpracy w dotychczasowych ramach.

Po pierwsze autorzy zwracają uwagę na konieczność wzmocnienia inter-operacyjności australijskich i amerykańskich sił zbrojnych poprzez regularne ćwiczenia i manewry. Jednym z przykładów takich działań są odbywające się cyklicznie co dwa lata od 2005 roku Exercise Talizman Saber. Głównym celem tych manewrów, w których udział bierze blisko 25 tysięcy żołnierzy z obu krajów, jest koordynacja dowodzenia sił zbroj- 
nych, w tym jednostek specjalnych i powietrznodesantowych, wobec nagłych wyzwań trwającej od 2001 roku globalnej wojny z terroryzmem (Talizman Saber 2013).

Po drugie zwraca się uwagę na konieczność implementacji Defense Trade Cooperation Treaty - umowy podpisanej między rządami USA i Australii regulującej warunki współpracy w zakresie handlu sprzętem wojskowym i technologiami z zakresu obronności (A-USDCTC 2013). Zapisy tego dokumentu pozwalają na ograniczenie procedur eksportowych wspomnianej kategorii sprzętu poprzez zniesienie obowiązku wystawiania licencji wymaganych wewnętrznymi ograniczeniami eksportu broni z USA. Pomoże to zacieśnić współpracę militarną między tymi państwami i przyspieszyć proces wykorzystania najnowszych technologii wojskowych $\mathrm{w}$ australijskich siłach zbrojnych.

Po trzecie Narodowa Strategia Bezpieczeństwa zwraca uwagę na konieczność kontynuacji i wzmocnienia regularnego dialogu ministerialnego między Canberrą a Waszyngtonem w zainicjowanej w 1985 roku formule AUSMIN (Australia-United States Ministerial Consultation) (AUSMIN 2012). Są to regularne spotkania ministrów spraw zagranicznych i obrony narodowej, których przedmiotem są najważniejsze problemy i wyzwania dla bezpieczeństwa i stabilności w regionie Azji i Pacyfiku, w kontekście dwustronnych relacji miedzy Australią a Stanami Zjednoczonymi.

Formuła ta jest w wybranych kwestiach rozszerzona także o Japonię, która stanowi jeden z filarów amerykańskiej polityki wobec całego regionu. Trójstronny Dialog Strategiczny, jak oficjalnie nazywane są te konsultacje pozwala trzem rządom koordynować działania wobec największych zagrożeń w regionie i ustalać wspólne priorytet w ich zwalczaniu (Tow 2009).

Po czwarte podniesiony został temat bezpośredniej współpracy bojowej i wywiadowczej obu stron. Jako kraj wymagający ciągłego zaangażowania Zachodu został wymieniony Afganistan, gdzie wspólnie z siłami NATO służy blisko półtora tysiąca australijskich żołnierzy. Jest to obecnie najbardziej klarowny przykład zbieżności australijskich i amerykańskich interesów w dziedzinie bezpieczeństwa. Drugim takim przykładem jest porozumienie o rozmieszczeniu do 2017 roku blisko 2,500 żołnierzy amerykańskiej piechoty morskiej w bazie australijskiego lotnictwa w położonym na północy kraju Darwin. Decyzja ta mimo wielu głosów sprzeciwu, zwłaszcza ze strony azjatyckich sąsiadów Australii jest uważana za konieczną, choć jej implementacja napotyka na wiele trudności, zwłaszcza logistycznych i finansowych (Chang 2013).

Wzrost aktywności chińskiej marynarki wojennej na wodach otaczających Japonię, głównego amerykańskiego sojusznika w regionie wschodniego Pacyfiku i zagrożenie atakami rakietowymi ze strony Korei Północnej zmuszają USA do szukania lokalizacji dla swoich baz $\mathrm{w}$ regionie Azji 
i Pacyfiku położonych poza strefą bezpośredniego zagrożenia. W tym kontekście położenie Australii jest niebywałym atutem z geopolitycznego punktu widzenia. Amerykańska obecność militarna w Australii, kraju najbardziej narażonym na infiltrację przez radykalnych islamistów z Azji Południowo-Wschodniej, ma również na celu przeciwdziałanie terroryzmowi.

\section{Podsumowanie}

W obliczu przeobrażeń globalnego układu sił, w którym kluczową rolę odgrywają państwa azjatyckie, Australia przestaje być jedynie mocarstwem drugiego rzędu powiązanym sojuszem militarnym z USA, ale staje się niezwykle asertywnym graczem na międzynarodowej szachownicy. Okres sprawowania władzy przez konserwatywny rząd Johna Howarda był bez wątpienia ostatnim, w którym bliskie związki z USA były traktowane jako priorytet, zarówno na płaszczyźnie politycznej jak i ekonomicznej. Będąca u władzy od 2008 roku Partia Pracy sukcesywnie dywersyfikuje możliwości międzynarodowej współpracy i działa na rzecz budowy czegoś więcej niż doraźnej współpracy handlowej z państwami azjatyckimi. Dowodem takiego rozumowania jest dokument Australia in the Asian Century White Paper, który formułuje kompleksowe wnioski dla Australii na najbliższe lata.

Wśród australijskich elit wciąż żywe są jednak obawy o los tego wyspiarskiego państwa w nowym, międzynarodowym układzie sił z silną pozycją Pekinu. Oprócz kalkulacji czysto ekonomicznych obawy te uwzględniają tradycyjne zagrożenia i postrzegają strategiczną przyszłość Australii z innej, mniej optymistycznej perspektywy. Właśnie ich wyrazem jest tegoroczna Narodowa Strategia Bezpieczeństwa, która dostrzega nierozerwalny związek między zdolnościami do reagowania australijskich sił zbrojnych a ścisłym sojuszem ze Stanami Zjednoczonymi. Współpraca ta, trwająca od 1941 roku stanowi punkt odniesienia do jakichkolwiek nawiązań do bezpieczeństwa regionalnego. Australia jest dla USA drugim po Japonii kluczowym partnerem w regionie Azji i Pacyfiku i pozostanie nim bez względu na pogłębiające się więzi gospodarcze z Chinami. Tradycja wspólnych operacji wojskowych w regionie, współpraca technologiczna i korzystanie ze wspólnych rozwiązań w zakresie obronności, oparcie siły militarnej na flocie, regularne manewry wojskowe i wreszcie amerykańska obecność militarna w Darwin sprawiają, że w kwestiach bezpieczeństwa nie ma alternatywy dla przyjętego przez australijskie elity strategicznego sojuszu z USA.

Widzimy, więc w jak trudnym położeniu znajduje się rząd w Canberrze, który próbując szukać kluczowych partnerów w Azji, wciąż jest postrzegany jako część innej, obcej cywilizacji, która oprócz historycznej już tradycji 
kolonializmu reprezentuje również amerykańskie interesy militarne w regionie. $\mathrm{O}$ ile dysonans ten nie stanowi przeszkody w bieżącej współpracy handlowej, co widać na wykresach przedstawiających wartość handlu zagranicznego między Australią a jej azjatyckimi partnerami, o tyle w sytuacji poważnego konfliktu (np. w wyniku eskalacji sporu terytorialnych między Chinami a Japonią lub jednym z państw Azji Południowo-Wschodniej) będzie niewystarczający do zachowania neutralności i realizowania strategii korzystania z efektów azjatyckiego wzrostu gospodarczego.

Stąd właśnie wynika obecność Australii we wszystkich możliwych regionalnych formach współpracy, gdzie korzystając z narzędzi dyplomatycznych można łagodzić bieżące spory i budować wizerunek aktywnego członka wspólnoty międzynarodowej zaangażowanego w problemy Azji Wschodniej.

\section{Bibliografia}

ASEAN Free Trade Area (http://www.asean.org/communities/asean-economic-community/ category/asean-free-trade-area-afta-council, dostęp 13.03.2013).

Australia - Country Fact Sheet. (http://www.dfat.gov.au/geo/fs/aust.pdf, dostęp 13.03.2013).

Australia in the Asian Century White Paper. (http://asiancentury.dpmc.gov.au/sites/ default/files/white-paper/australia-in-the-asian-century-white-paper.pdf, dostęp 13.03.2013).

Australia's Trade Agreements. (http://www.dfat.gov.au/fta/, dostęp 13.03.2013).

Australia's Trade in Goods and Services by Top Ten Partners. (http://www.dfat.gov. $\mathrm{au} /$ publications/tgs/Australias-goods-services-by-top-10-partners-2011.pdf, dostęp 13.03.2013).

Australia-United States Defence Trade Cooperation Treaty (http://www. defence.gov.au /ustradetreaty/, dostęp 13.03.2013)

AUSMIN-Australia-United States Ministerial Consultations. (http://www.dfat.gov.au/ geo/us/ausmin/index.html, dostęp: 13.03.2013).

Burke, Anthony. Fear of Security: Australia's Invasion Anxiety. Cambridge: Cambridge University Press, 2008.

Chang, Felix K. Sideways: America's Pivot and its Military Bases in the Asia-Pacific, Sideways: America's Pivot and its Military Bases in the Asia-Pacific. (http://www.fpri.org/articles/ 2013/04/sideways-americas-pivot-and-its-military-bases-asia-pacific, dostęp 23.10.2013).

Defence White Paper (http://www.defence.gov.au/oscdf/se/publications.htm, dostęp 13.03.2013).

Firth, Stewart. Australia in International Politics: An Introduction to Australian Foreign Policy. Sydney: Allen \& Unwin, 2011.

International Trade in Goods and Services. (http://www.ausstats.abs.gov.au/ausstats/ meisubs. nsf/0/31AB03C35A7851FBCA257B26000BD957/\$File/53680_jan\%202013.pdf, dostęp 13.03.2013).

KYODO Agency. Japan, Australia apart on FTA Talks. 2012. (http://www.japantimes. co.jp/news/2012/04/24/business/japan-australia-apart-on-fta-talks/\#.UmhR-HDsrZJ, dostęp 23.10.2013). 
Mediansky, F. A. Australian Foreign Policy: Into the New Millennium. Sydney: Macmillan Education AU, 1997.

Paul, Erik. Neoliberal Australia and US Imperialism in East Asia. Canberra: Palgrave Macmillan, 2012.

Ravenhill, John. APEC and the Construction of Pacific Rim Regionalism. Cambridge University Press: Cambridge, 2001.

Strong and Secure. A Strategy for Australia's National Security (http://www.dpmc.gov.au /national_security/docs/national_security_strategy.pdf, dostęp 13.03.2013).

Talisman Saber 2013 (http://www.defence.gov.au/opEX/exercises/ts13/index.html, dostęp 13.03.2013).

Terada, Takashi, Song Ligang. Japan's Future in East Asia and the Pacific. Canberra: ANU Press, 2007.

Tow, William. Assessing the Trilateral Strategic Dialogue. 2009. (http://www. eastasiaforum.org/2009/02/12/assessing-the-trilateral-strategic-dialogue/, dostęp 13.03.2013).

Williams, Brad, Newman Andrew. Japan, Australia and Asia-Pacific Security. Abingdon: Taylor \& Francis, 2006.

\title{
Australia's Policy at the Threshold of the $21^{\text {st }}$ Century
}

\author{
Summary
}

The Australia's foreign policy traditionally focused mainly on the relations with the US has changed in recent years. The evolution of the balance of power in the global politics, felt most in the East Asian region, has led to the appreciation in the eyes of the Australian elite of partners from the immediate neighborhood. PRC, currently the most important economic partner of Canberra, but also traditionally the biggest threat to the regional balance of power, aspires to play a key role in the South Pacific. Through the establishment of free trade agreements with countries of the ASEAN and with this organization separately, Australia is trying to provide a counter-balance for Beijing's privileged position as a major trading partner. Another step in this direction will be elimination of taxes and tariffs in trade with South Korea and Japan. My essay examines the shift in Asian Australian foreign policy in recent years and illuminates the contents of documents, defining the economic and military strategy of the Australian government in new geopolitical circumstances. 